\title{
Correlation with Internet Finance and Residence Consumption
}

\author{
Tie Jing* \\ International Business School \\ Yunnan University of Finance and Economics \\ Kunming,China \\ 123278697@qq.com
}

Zhao Wenjing

\author{
Statistics and Mathematics School \\ Yunnan University of Finance and Economics \\ Kunming, China \\ Dai $\mathrm{Yu}$ \\ International Business School \\ Yunnan University of Finance and Economic \\ Kunming, China
}

\begin{abstract}
Cui (2014) illustrated that, in recent years, the development of Chinese Internet finance has not only deeply changed Chinese financial system, but also influenced the way people live as well. China is spending a period, which transferred the cash society to cashless society. Market participants will become a whole through the Internet. Internet finance has led to non-financial institutions involved in the financial services industry, which represented by electricity business enterprises. And Internet finance has caused a great impact on the past model of financial industry. However, Chinese researchers are less likely to analyze the Internet finance impact on consumers in a macro perspective. This paper will use the dynamic time series model to analyze the impact of GDP and Internet payments on Chinese residents' consumption. The data range is from 2005 to 2015. The results show that GDP and Internet payments have had a positive impact on Chinese residents' consumption.
\end{abstract}

Keywords-internet finance Chinese financial system dynamic time series model

\section{INTRODUCTION}

Tang [12] thought that Internet finance was a combination of Internet information technology and traditional finance. $\mathrm{Li}$ (201) said that before 2005, the combination of Internet and finance is mainly reflected in the bank's mobile business online. There is no real sense of the Internet financial format. Andrianaivo and Kpodar (2011) analyzed the impact of information and communication technology (ICT) on finance, which believing that mobile phone development reduced the cost of access to financial resources and contributed to economic growth. Chinese scholars mainly study the difference between Internet finance and traditional finance [4]. Zhuo (2012) believed that Internet finance has difference between narrow sense and broad sense. From narrow sense, the Internet finance is based on information technology to carry out financial transactions. From a broad sense [6], the Internet finance means all financial services that can operate on an international scale, which based on network information technology. Xie (2012) thought that Internet finance was not only different from the commercial banks indirect financing model [5], but also different from the capital market direct financing model. $\mathrm{Hou}(2013)$ said that Internet finance enables customers to enjoy personalized, integrated and convenient financial

\footnotetext{
* Corresponding author
}

services atanywhere and anytime, which mainly include online banking, online insurance, online securities and internet payments and other financial activities. Internet finance has the characteristics of low cost and high efficiency, which brings great economic and social benefits.

\section{LITERATURE REVIEW}

Liu [13] believed that the network economy is built on the basis of the information internet of modern communications internet. Through the computer' Internet, the economic activities to form a whole. The most fundamental feature of the internet economy is the Internet, economic actors through the enterprise network, shared external network or public Internet link. As a result of the development of the telecommunications industry, satellite and mobile technology, which means that anyone can connect to any business or personal network at any time [1], so that they can obtain any information, products and services they need in a timely manner. As the Internet economy is based on the speed of information transmission, which makes the interaction between people is not only very extensive, and very fast. This technological revolution makes the operating the way is different between the Internet economy and the traditional economy.

Tan (2005) pointed out that the traditional economy and the commodity economy more closely. The traditional economy has a greater chance of appearing in rural society, due to the need to address three basic economic problems. The three economies are planned economy, market economy and mixed economy. [2]

High (2014) pointed out that Internet finance refers to traditional financial institutions and Internet companies to use Internet technology and information and communication technology to achieve the Internet as a financial intermediary, Internet payment, investment and information intermediary services. This is the new financial [3] business model. Internet finance is not a simple combination of the Internet and the financial industry, which is in the realization of security, mobile and other aspects of network technology so that users familiar with and accept such a way. So that customers naturally adapt to new needs, these needs include new models 
and new business. This is the best result of the financial industry combination with the Internet technology.

William (2014) said that the traditional financial industry mainly refers only to three kinds of traditional commercial financial activities, these three activities are: deposits, loans and settlement. Financial activities Extensive life cycle costs should also include the cost of purchasing and wasting costs for consumers [7]. All in all, finance is financing. Finance is the general term for general currency circulation and credit activities and related economic activities. It generally refers to all financial and credit currency issuance, custody, exchange, settlement and financing and other economic activities, including gold and silver transactions. Narrowly defined financial is specifically refers to the involvement of credit currency [8]

Zhang (2014) thought that Internet finance is different from traditional financial positioning, mainly because of the advantages of Internet financial use of the economic and marginal costs of the information technology revolution, which allows long tail customers to gain access to small-scale transactions and market segments Effective financial services [9]. For example, Internet finance in the real estate mortgage market can provide users with real estate information as part of the order of this drive factor. Traditional financial industry is process-oriented, focusing on direct communication with customers, face to face in the process of collecting information, the establishment of risk control mechanisms or delivery services. Internet financing is data-driven demand, customization of various structured information can become the basis of marketing and risk control.

Marx, in Capital, Vol. I (1867), has pointed out that people in the beginning of production and consumption before, people have been on the planet every day consumption. Adam Smith pointed out in the "Wealth of Nations" (1776) that the lack of capital, extravagance and waste will lead to the reduction of arbitrary capital. How much money a person can increase from the savings on the one hand, he emphasizes consumption because the accumulated capital will be used for social production. On the other hand, we should pay attention to the important role of consumption on production.Keynes in the Theory of Employment Interests and Money (1936) points out that consumption is the ultimate goal of all natural and sole purpose [11]. Total demand can only come from current consumption or is now ready for future consumption.

Cui (2016) pointed out that gross domestic product and Internet payments have a positive impact on household consumption. According to the data analysis, the conclusion is that for every $100 \%$ increase in GDP in 2014, the consumption of residents increased by 1.388 billion yuan. The increase in the amount of Internet payment transactions will increase by RMB100.17 million [14]. From this analysis, something can be seen, which is that to speed up the development of Internet finance, will be able to increase consumption of consumer spending. Relevant departments need to further strengthen the supervision of Internet finance, to prevent the theft of funds trading process, fraud, which can create a safe and reliable consumer network environment. At the same time, it can also promote China's consumption growth.

\section{IMPACT OF INTERNET FINANCE ON CONSUMPTION IN CHINA}

This paper uses the Chinese residents' consumption, gross domestic product (GDP) and Internet payment scale from 2005 to 2015 as samples. In order to eliminate the impact of inflation on the selected variables, the data used in this paper are true values. Because of the large gap between rich and poor in China, the consumption of residents used in this paper adopts the consumption of urban residents and the consumption of rural residents respectively [10]. This can also reduce the analysis of the error, from a more objective point of view as well. Unit root test refers to the existence of unit roots, because there is a unit root is a non-stationary time series. Unit root refers to the unit root process.

Traditional asset-liability management is too dependent on the analysis of financial institutions; lack of timeliness, asset pricing model (CAPM) cannot blend new financial derivatives These traditional methods are difficult to accurately define and measure the financial risks of financial institutions. In 1993, the G30 Group presented the VAR model in the report of "Derivatives Practice and Rules"

Figure 1 shows that from 2005 to 2015, GDP showed a clear upward trend, which represents the income of Chinese residents also showed an upward trend. From Figure 2, 2005 to 2015 , China Internet payment scale is on the rise, which represents Chinese Internet finance is in a period of rapid development. Figure 3 shows that Chinese urban residents increased year by year. Figure 4 shows that Chinese Consumption of rural residents overall consumption is on the rise. This may be related to the construction of new rural areas in China.

According to Keynes (1936) absolute income hypothesis consumption theory, consumption is determined by the current income, and there is a stable function relationship between consumption and income. With the increase in income levels, consumption will increase, but the increase in consumption is lower than the increase in income, that is, the marginal propensity to consume is decreasing [15]. In order to reflect the impact of income on consumption, this paper chooses China's gross domestic product to represent income and consumption to express consumption. Internet finance, the size of the Internet to pay the transaction size of the financial transactions accounted for a larger proportion of Internet transactions, and the impact of the largest consumer spending, so the size of the Internet to pay the transaction to the performance of Internet financial indicators [16]. The explanatory variables selected in this paper are the consumption of urban residents and the consumption of rural residents. The explanatory variables are the gross domestic product and the Internet pay respectively. 
TABLE I. ADF TEST RESULTS

\begin{tabular}{|c|c|c|c|c|c|}
\hline \multicolumn{6}{|c|}{ ADF } \\
\hline Vanabler & t-Statistice & $5 \% \%$ & $10 \%$ & AIC & Stationanity \\
\hline GDP & 0.699632 & $-1.988198 \mathrm{e}$ & -1.600140 & $16.742630 \mathrm{P}$ & No \\
\hline $\mathbb{P}^{p}$ & $.2867932{ }^{\circ}$ & $4.008157 \%$ & $.3 .460791 \%$ & $15.187420 \mathrm{e}$ & No \\
\hline CUR & .5681732 & 4.246503 & .3590496 & 5.261366 & No \\
\hline CRR & 0.274723 & $4.107833 \mathrm{P}$ & $.3 .515047 \%$ & $8.013187 \%$ & .10 \\
\hline$D(G D P)$ & $4.742727 \%$ & $4.246503 \mathrm{P}$ & .3 .590496 & $15.169600 \mathrm{u}$ & YES \\
\hline$D(\mathbb{P})^{2}$ & .5 .593454 & $-4.450425 \mathrm{e}$ & .3 .701534 & $14.423900 \mathrm{e}$ & YES \\
\hline$D(\mathrm{CUR})^{p}$ & 4.567035 & 4.107833 & .3 .515047 & 7.186381 & YES \\
\hline$D(\text { CRR })^{\mu}$ & 4.356483 & 4.107833 & $-3.515047 \mathrm{e}$ & 7.805947 & YESP \\
\hline
\end{tabular}

From Table 1 shows that although GDP, IP, CURandCRR is non-stationary, but they are after the first-order difference is smooth. Therefore, the description of GDP, IP, CUR \& CRR there is a long-term correlation, so can build VAR model.

\begin{tabular}{|c|c|c|c|}
\hline & $\mathrm{D}(\mathrm{CUR})$ & $D(G D P)$ & $\mathrm{D}(\mathbf{I P})$ \\
\hline$D(C U R(-1))$ & $\begin{array}{r}0.049891 \\
(1.21481) \\
{[0.04107]}\end{array}$ & $\begin{array}{l}47.64296 \\
(88.9075) \\
{[0.53587]}\end{array}$ & $\begin{array}{l}42.05463 \\
(70.7727) \\
{[0.59422]}\end{array}$ \\
\hline $\mathrm{D}(\mathrm{CUR}(-2))$ & $\begin{array}{l}0.472607 \\
(0.85281) \\
{[0.55418]}\end{array}$ & $\begin{array}{l}21.35352 \\
(62.4140] \\
{[0.34213]}\end{array}$ & $\begin{array}{r}-7.845374 \\
(49.6832) \\
{[-0.15791]}\end{array}$ \\
\hline $\mathrm{D}(\operatorname{GDP}(-1))$ & $\begin{array}{r}1.59 E-05 \\
(0.01196) \\
{[0.00133]}\end{array}$ & $\begin{array}{l}0.116601 \\
(0.87549) \\
{[0.13318]}\end{array}$ & $\begin{array}{r}-0.385329 \\
(0.69691) \\
{[-0.55291]}\end{array}$ \\
\hline $\mathrm{D}(\mathrm{GDP}(-2))$ & $\begin{array}{r}-0.003066 \\
(0.01311) \\
{[-0.23386]}\end{array}$ & $\begin{array}{r}-0.343711 \\
(0.95950) \\
{[-0.35822 \rrbracket}\end{array}$ & $\begin{array}{l}0.797856 \\
(0.76379) \\
{[1.04461]}\end{array}$ \\
\hline $\mathrm{D}(\mathbb{P}(-1))$ & $\begin{array}{r}-0.005784 \\
(0.01133) \\
{[-0.51037]}\end{array}$ & $\begin{array}{l}0.710671 \\
(0.82943) \\
{[0.85682]}\end{array}$ & $\begin{array}{r}-0.788172 \\
(0.66025) \\
{[-1.19375]}\end{array}$ \\
\hline$D(\mathbb{P}(-2))$ & $\begin{array}{r}0.002292 \\
(0.01285) \\
{[0.17838]}\end{array}$ & $\begin{array}{l}0.965590 \\
(0.94028) \\
{[1.02692]}\end{array}$ & $\begin{array}{r}0.456149 \\
(0.74849) \\
{[0.60943]}\end{array}$ \\
\hline c & $\begin{array}{r}50.48647 \\
(87.6407) \\
{[0.576061} \\
\end{array}$ & $\begin{array}{r}2202.388 \\
(6414.13) \\
{[0.34337]} \\
\end{array}$ & $\begin{array}{r}-2344.078 \\
(5105.82) \\
{[-0.45910]} \\
\end{array}$ \\
\hline $\begin{array}{l}\text { R-squared } \\
\text { Adj. R-squared } \\
\text { Sum sq. resids } \\
\text { S.E. equation } \\
\text { F-statistic } \\
\text { Log likelihood } \\
\text { Akaike AIC } \\
\text { Schwarz SC } \\
\text { Mean dependent } \\
\text { S.D. dependent }\end{array}$ & $\begin{array}{r}0.475044 \\
-2.674695 \\
177.1413 \\
13.30944 \\
0.150820 \\
-23.74153 \\
7.685383 \\
7.754895 \\
50.95000 \\
6.943034\end{array}$ & $\begin{array}{r}0.698889 \\
-1.107774 \\
948819.3 \\
974.0735 \\
0.386840 \\
-58.08564 \\
16.27141 \\
16.344092 \\
6739.378 \\
670.9339\end{array}$ & $\begin{array}{l}0.740467 \\
-0.816733 \\
601227.1 \\
775.3884 \\
0.475512 \\
-56.26065 \\
15.81516 \\
15.88467 \\
1544.125 \\
575.2727\end{array}$ \\
\hline $\begin{array}{l}\text { Determinant resic } \\
\text { Determinant resic }\end{array}$ & (dof adj-) & $\begin{array}{l}0.0000000 \\
0.000000\end{array}$ & \\
\hline
\end{tabular}

Fig. 1. VAR model checklist of CUR
$\mathrm{D}(\mathrm{CUR})=0.0499 * \mathrm{D}(\mathrm{CUR}(-1))+0.4726 * \mathrm{D}(\mathrm{CUR}(-2))$

$+1.5932 * \mathrm{D}(\mathrm{GDP}(-1))-0.0031 * \mathrm{D}(\mathrm{GDP}(-2))-0.0058 * \mathrm{D}(\mathrm{IP}(-1))$ $+0.0023 * \mathrm{D}(\mathrm{IP}(-2))+50.4865$

The model is stable by unit root test. This shows that GDP and IP have a positive impact on the CUR, that is, when the GDP increased by 100 billion yuan, CUR increased by 159.3 million yuan. When the IP increased by 100 billion yuan, CUR increased by 0.0058 billion yuan.

\begin{tabular}{|c|c|c|c|}
\hline & $\mathrm{D}(\mathrm{CRR})$ & $\mathrm{D}(\mathrm{GDP})$ & $\mathrm{D}(\mathrm{IP})$ \\
\hline $\mathrm{D}(\mathrm{CRR}(-1))$ & $\begin{array}{l}0.022216 \\
(1.01958) \\
{[0.02179]}\end{array}$ & $\begin{array}{l}1.574313 \\
(12.1071) \\
{[0.13003]}\end{array}$ & $\begin{array}{r}-4.948152 \\
(0.99666) \\
{[-4.96473]}\end{array}$ \\
\hline $\mathrm{D}(\mathrm{CRR}(-2))$ & $\begin{array}{c}0.484848 \\
(0.82450) \\
{[0.58805]}\end{array}$ & $\begin{array}{l}4.789908 \\
(9.79060) \\
{[0.48924]}\end{array}$ & $\begin{array}{r}-8.961915 \\
(0.80596) \\
{[-11.1195]}\end{array}$ \\
\hline $\mathrm{D}(\mathrm{GDP}(-1))$ & $\begin{array}{r}-0.011485 \\
(0.05881) \\
{[-0.19528]}\end{array}$ & $\begin{array}{l}0.497792 \\
(0.69839) \\
{[0.71277]}\end{array}$ & $\begin{array}{l}-0.284753 \\
(0.05749) \\
{[-4.95297]}\end{array}$ \\
\hline $\mathrm{D}(\operatorname{GDP}(-2)))$ & $\begin{array}{r}-0.004861 \\
(0.06587) \\
{[-0.07380]}\end{array}$ & $\begin{array}{r}-0.111370 \\
(0.78216) \\
{[-0.14239]}\end{array}$ & $\begin{array}{l}0.375807 \\
(0.06439) \\
{[5.83668]}\end{array}$ \\
\hline $\mathrm{D}(\mathbb{P}(-1))$ & $\begin{array}{r}0.042926 \\
(0.08371) \\
{[0.51280]}\end{array}$ & $\begin{array}{l}0.690814 \\
(0.99400) \\
{[0.69498]}\end{array}$ & $\begin{array}{r}-0.958988 \\
(0.08183) \\
{[-11.7198]}\end{array}$ \\
\hline$D(\mathbb{P}(-2))$ & $\begin{array}{c}0.042872 \\
(0.07103) \\
{[0.60361]}\end{array}$ & $\begin{array}{l}0.993420 \\
(0.84340) \\
{[1.17788]}\end{array}$ & $\begin{array}{l}-0.367947 \\
(0.06943) \\
{[-5.29965]}\end{array}$ \\
\hline c & $\begin{array}{r}19.43074 \\
(816.416) \\
{[0.02380]}\end{array}$ & $\begin{array}{l}1213.288 \\
(9694.62) \\
{[0.12515]}\end{array}$ & $\begin{array}{r}4004.708 \\
(798.062) \\
{[5.01804]}\end{array}$ \\
\hline $\begin{array}{l}\text { R-squared } \\
\text { Adj. R-squared } \\
\text { Sum sq. resids } \\
\text { S.E. equation } \\
\text { F-statistic } \\
\text { Log likelihood } \\
\text { Akaike AlC } \\
\text { Schwarz SC } \\
\text { Mean dependent } \\
\text { S.D. deppendent }\end{array}$ & $\begin{array}{r}0.635927 \\
-1.548511 \\
6967.459 \\
83.47130 \\
0.291117 \\
-38.42977 \\
11.35744 \\
11.42695 \\
72.08750 \\
52.28702\end{array}$ & $\begin{array}{r}0.688215 \\
-1.182498 \\
982456.3 \\
991.1893 \\
0.367889 \\
-58.22499 \\
16.30625 \\
16.37576 \\
6739.378 \\
670.9339\end{array}$ & $\begin{array}{l}0.997126 \\
0.979882 \\
6657.716 \\
81.59483 \\
57.82547 \\
-38.24787 \\
11.31197 \\
11.38148 \\
15.44 .125 \\
575.2727\end{array}$ \\
\hline
\end{tabular}

Fig. 2. VAR model checklist of CRR

\section{RESULTS}

The model is stable by unit root test. This shows that GDP and IP have a positive impact on the CUR, that is, when the GDP increased by 100 billion Yuan, CUR increased by 159.3 million Yuan. When the IP increased by 100 billion Yuan, CUR increased by 0.0058 billion Yuan. The model is stable by unit root test. This shows that GDP and IP have a positive impact on the CRR, that is, when GDP increased by 100 billion Yuan, CRR increased by 48.88 million Yuan. When IP increased by 100 billion Yuan, CRR increased by 0.0429 billion Yuan [17].

From the comparison between urban and rural areas, the impact of Internet finance on urban residents' consumption is greater than that on rural residents. It is of great significance to promote the financial use of Internet in rural areas and to expand the consumption demand of rural residents and promote the balanced development of urban and rural residents [18]. In general, Internet finance has had a positive impact on the population. The development of Internet finance can stimulate the consumption of residents. With the development of the Internet, the role of Internet finance gradually highlighted. The Constraints of Internet Development

Compared with the physical market, the Internet market to cultivate the early investment, slow return on investment, the initial start of the Internet business platform and market development costs are too large, long profit cycle, entrepreneurial innovation risk. With the establishment of 
independent e-commerce platform enterprises in the early stage, platform construction and maintenance costs to more than $70 \%$ of the total cost, put into operation, the platform to promote and market development (Internet traffic acquisition, a variety of media advertising, etc.) cost the total cost of 50 $\%$ the above. The Internet financial age mainly refers to the financial services sector, especially the banking industry, in their own development process of an innovation period. In recent years, many of the financial business must rely on online operations to achieve, especially some online financial transactions, online banking, e-commerce and Internet payments and other financial services.

Small micro-e-commerce business development of public services is lagging behind, the lack of professional photography, art, warehousing outsourcing, on behalf of the operation, training, creativity, marketing and other services; small Internet vendors selling product categories simple, small storage, High delivery costs. The introduction and financing of talents in e-commerce enterprises are restricted. Talent is e-commerce enterprises are facing outstanding problems, high-level talent, especially the leading talent is very lacking. The financing system for e-commerce enterprises needs to be further improved, and the government guidance policy to encourage venture capital has yet to be established.

\section{CONCLUSION}

The study found a lot of valuable data to help people better understand the relationship between Internet finance and consumer spending.

From the data analysis results, the Internet finance and GDP have had a positive impact on the residents, of which the impact of urban residents in rural areas. This is consistent with the objective reality of the urban residents' physical market, the consumption conditions are better, the diversification of the consumption channels, and the willingness to consume are easier to meet. Indicating that the Internet consumption channels for rural residents, the realization of potential consumer demand for the significance and role of the more significant for the government to expand the rural residents demand for consumption policy practice provides a new way and way. Theoretical research shows that the rapid development of third-party payments can promote the improvement of consumption level. In terms of resource allocation, the borrower of funds can achieve the purpose of consumption ahead and can delay the borrower. It can be seen that the development of Internet finance can indeed increase the consumption expenditure of residents, to create a safe network environment, only to expand domestic demand and ensure the healthy and sustainable development of the national economy.

\section{ACKNOWLEDGMENT}

Thanks the supporting of Yunnan Province Applied basic research project 2016FD062.

\section{REFERENCES}

[1] A. Agrawal, C. Catalini, and A. Goldfarb, "The Geography of Crowdfunding”, NBER Working Paper, 2011.

[2] A. Agrawal, C. Catalini, and A. Goldfarb, "Goldfarb Catalinimics of Crowdfunding", NBER Working Paper, 2013.

[3] F. Allen, J. McAndrews, and P. Strahan, "E-finance: A Introduction", Journal of Financial Services Research, vol. 22, 2002, pp. 130-141.

[4] M. Andrianaivo, and K. Kpodar, "ICT, Financial Inclusion and Growth:Evidence from African Countries,” IMF Working Paper, 2011.

[5] M. Armstrong, "Competition in Two-sided Markets", RAND Journal of Economics, vol. 37, 2006, pp. 668-691.

[6] S. Barati, and S. Mohammadi, "An Efficient Model to Improve Customer Acceptance of Mobile Banking," World Congresson Engineering and Computer Science, vol. 2, 2009.

[7] Y.F. Chen, "The Current Situation and Restrictive Factors of Network Consumption in Hunan," China Statistics, 2013.

[8] L. Chen, D. Woods, K. Curran, and J. Doherty, "Mobile Development Environments for Electronic Finance," International Journal of Electronic, vol. 4, 2010, pp. 99-119.

[9] Y.F. Chen, "The Current Situation and Restrictive Factors of Network Consumption in Hunan,"China Statistics, 2013.

[10] Y. Dong, and X. Li, "The development of Internet finance: based on literature," Financial Review, 2014, pp. 16-40.

[11] J. Durate, S. Siegel, and L. Young, "Trust and Credit", Review of Financial Studies, vol. 25, 2012, pp. 2455-2484.

[12] D. Hancock, D. Humphrey, and J. Wilcox, "Cost Reductions in Electronic Payments", Journal of Banking \& Finance, vol. 23,1999, pp. 391-421.

[13] N. Hensel, "An Empirical Analysis of the Efficiency of Online Auction IPO Processes and Traditional IPO Processes," International Journal of Managerial Finance, vol. 5, 2009, pp. 268-310.

[14] Leland, and E. Hayne, "Saving and Uncertainty: the Precautionary Demand for Saving," Quarterly Journal of Economics, vol. 82, 1968.

[15] L.Liu, "Research on the Current Situation and Tendency of Internet Finance," Financial Times, 2013, pp. 177-177.

[16] P. Dandapani, K.G. Karels and E. Lawrence, "Internet Banking Services and Credit Union Performance”, Managerial Finance, vol. 34, 2008, pp. 437-446.

[17] D.D. Wang, "The Internet Age of Internet Finance and Financial Development," International Business Accounting, 2013, pp. 63-65.

[18] D.D. Wang, "The Study of Internet Finance's Development in China," Jilin University, vol. 35, 2015, pp. 192-193. 